\title{
EKONOMICKÉ ZHODNOTENIE REVITALIZÁCIE BROWNFIELDU NOVÁ CVERNOVKA
}

\author{
ECONOMIC EVALUATION OF BROWNFIELD NOVA CVERNOVKA \\ REVITALISATION
}

\author{
Jakub Sabo ${ }^{*}, 1$
}

jakub.sabo93@gmail.com

${ }^{1}$ Vysoké Učení Technické Fakulta Stavební

\begin{abstract}
Abstrakt
Článok sa zaoberá ekonomickým zhodnotením revitalizácie brownfieldu Nová Cvernovka v Bratislave na Slovensku. Tento brownfield bola bývala chemická škola, ktorá bola zrevitalizovaná na multifunčkné centrum primárne zamerané pre umenie, konkrétne ateliéry a kultúrne podujatia. Zároveň revitalizáciou v oblasti vzniklo mnoho iných spoločensky prospešných benefitov. Ekonomické zhodnotenie bolo prevedené na základe CBA analýzy. Od Nadácie Nová Cvernovka boli získané potrebné ako investičné náklady, prevádzkové náklady, použité finančné granty a finančné zisky. Socio-ekonomické benefity boli vytvorené na základe informácii o revitalizácii a vyčíslené pomocou aplikácie eCBA.cz.
\end{abstract}

\section{Klíčová slova}

Brownfield, revitalizácia, socio-ekonomické benefity, CBA analýza, Nová Cvernovka

\begin{abstract}
The article deals with the economic evaluation of the revitalization of the Nová Cvernovka brownfield in Bratislava, Slovakia. This brownfield was a former chemical school that was revitalized into a multifunctional center primarily focused on the arts, specifically studios and cultural events. At the same time, the revitalization in the area has created many other socially beneficial benefits. Economic evaluation was analysed by CBA analyse. The necessary data such as investment costs, operating costs, used financial grants and financial profits, were obtained from the "Nadácia Nová Cvernovka". The socio-economic benefits were created on the basis of revitalization information and quantified using the eCBA.cz application.
\end{abstract}

Key words

Brownfield, revitalisation, socio-economic benefits, CBA analyse, Nova Cvernovka

\section{1 ÚVOD}

Brownfieldy sú v dnešnej dobe vel'mi rozsiahli problém, ked’že po ukončených výrobách a t’ažbách sa ich na Slovensku a v Českej republike stále nachádza vel'ké množstvo [1]. Často so sebou nesú ekologickú a ekonomickú zát’až. Revitalizácia brownfieldov je v dnešnej dobe našt'astie vel'mi moderná a mestá a obce ktoré majú na svojom území brownfieldy, začínajú byt' k revitalizáciám brownfieldov často naklonené [1], [2],[4]. Podobným procesom nielen že odstránia často prípadnú ekologickú zát’až brownfieldu, ale pri správnom výbere zamerania môžu priniest' aj množstvo socio-ekonomických benefitov pre spoločnost' [3], [4].

Ciel'om práce je určit', ako ekonomicky efektívne vychádza prípadová štúdia revitalizácie brownfieldu Nová Cvernovka, ktorá bola realizovaná v roku 2017 ako verejný projekt s podporou Bratislavského Samosprávneho Kraju a rôznych súkromných subjektov. V prípade kladných čísel čistého kumulovaného peňažného toku môže byt' použitá ako vzor pre d’alšie revitalizácie podobných objektov.

Niektoré revitalizácie sú aj podnikatel'ským zámerom právnických osôb, ale v tom prípade je možné predpokladat' nižšiu hodnotu socio-ekonomických benefitov, ked’že prioritou súkromného projektu je zisk a nie spoločenské blaho. Na základe toho bol vybraný verejný projekt s prioritou socio-ekonomických benefitov pred finančnými.

Jednou z najvhodnejších metód na posúdenie ekonomickej efektívnosti je CBA analýza ktorá bola pre posúdenie tejto prípadovej štúdie použitá [5]. Pomocou CBA analýzy boli porovnané všetky náklady voči 
finančným a socio-ekonomickým benefitom spojenými s revitalizáciou. Všetky náklady aj benefity boli diskontované v čase s diskontnou sadzbou častou pre verejné projekty, teda $5 \%$. Socio-ekonomické benefity boli vyčíslené pomocou programu eCBA.cz [9].

$\mathrm{Na}$ základe výsledkov tejto analýzy, hlavne dobe návratnosti vychádzajúcej z kumulovaného čistého peňažného toku, môžeme predpokladat efektivitu revitalizácie podobných objektov, kde existuje potencionálne využitie a tým prípadne motivovat' verejný alebo súkromný sektor.

\section{LITERÁRNÍ PŘEHLED}

So stále stúpajúcim počtom revitalizácii brownfieldov stúpa aj počet prác a literatúry venujúcej sa tejto téme. Základné teoretické informácie vychádzajú z knihy Boženy Kadeřábkovej a Mariana Piechy v knihe s názvom "Brownfields - jak vznikají a co s nimi." V tejto knihe je možné nájst' teoretické informácie o vzniku a rozdelení brownfieldov, ako aj možnosti vysporiadania sa s nimi. Ďalšie informácie môžeme nájst' v knihe "Současné formy užívání industriálních historických objektů" od Martiny Peřinkovej [1], [4].

Ďalšie Informácie o procesoch podobných revitalizácií v Európskej Únii sa dajú získat’ z článku Brownfield Redevelopment in the European Union a Brownfields - the need for policy, startegy and an institutional framework [6], [7].

Informácie o samotnej revitalizácii tejto prípadovej štúdie boli získavané primárne priamo od nadácie, ktorá sa o revitalizáciu pričinila a zároveň z internetových zdrojov [8].

Klasifikáciu a hodnotenie možností regenerácie brownfieldov bolo spracované aj na stránke uzemneplany.sk, ktorá rozdel'uje potenciál revitalizácie brownfieldov najmä podl'a jeho polohy a pôvodného zámeru [10]. O prístupe k potenciálu na základe polohy brownfieldu hovorí aj Finka M. v Plánovaní prestavby brownfieldu územné podmienky [11]. Táto metodológia ale nemusí byt' úplne postačujúca, ked’že je dôležité aj to, za akým účelom sa bude brownfield revitalizovat'. Objekt prípadovej štúdie brownfield Nová Cvernovka sa nachádza v okrajovej časti Bratislavy a je to bývalá chemická škola. Na základe tejto metodiky to teda nie je najideálnejší brownfield na revitalizáciu, ale konečné výsledky analýzy CBA hovoria o opaku.

Vzhl'adom na aktuálny stav témy podobným revitalizáciám sa autor venoval aj v rôznych článkoch publikovaných na rôznych konferenciách [12], [13], [14], [15].

\section{METODIKA}

Na ekonomické zhodnotenie revitalizácie bola použitá CBA analýza ktorá porovnáva náklady s benefitmi spolu s priamymi príjmami . Náklady tvorili investičné náklady a prevádzkové náklady. Benefity tvorili vyčíslené socioekonomické benefity ku ktorým boli pripočítané aj priame príjmy. Socio-ekonomické benefity boli vytvorené na základe informácii o revitalizácii a boli vyčíslené pomocou aplikácie eCBA.cz. Jedná sa o tieto benefity:

- $\quad$ Rozvoj zamestnanosti v regióne (RZR)

- Technické zhodnotenie pamiatok (TZP)

- Prírastok zahraničných jednodenných návštevníkov (PZJN)

- Prírastok prenocovania zahraničných turistov (PPZT)

- Prírastok domácich jednodenných návštevníkov (PDJN)

- Prírastok prenocovania domácich turistov (PPDT)

- Úspora času návštevníkov vd’aka novým službám (ÚČNVNS)

- Zlepšenie stavu infraštruktúry pre kultúru (ZSIPK)

- Zlepšenie stavu infraštruktúry pre šport a mládež (ZSIPŠM)

- Zlepšenie stavu parkov a verejnej zelene (kl’udové zóny) (ZSPVZKZ)

- Zlepšenie stavu verejných priestranstiev (mimo parky) (ZSVPMP)

- Úspora času pri parkovaní (ÚČPP)

- Rozšírenie cyklotrás (RC)

Hodnoty benefitov sú založené na predpokladaných počtoch l'udí, ktorých daný benefit ovplyvňuje. Vychádzajú z priemernej ročnej návštevnosti brownfieldu, počtu zamestnaných l’udí alebo prípadne návštevnosti oblasti za rôznymi účelmi. Je nutné podotknút', že v tret'om prípade sú čísla odhadnuté na hrubo na základe rôznych atribútov. Podrobnejšie rozvíjat' genézu jednotlivých benefitov a ich l'udí nimi ovplyvnenými by bolo vel'mi obšírne a nevošlo by sa do rámcu článku. Preto je na mieste podotknút', že niektoré čísla z ktorých bolo vychádzané môžu byt' nepresné, respektíve sú odhadnuté iba na hrubo. Jedná sa ale často o benefity s nízkou jednotkovou socio-ekonomickou hodnotou a teda ich nepresnost' ovplyvňuje celkové výsledky len minimálne. 
Všetky náklady a benefity sú rozprestreté v čase od začiatku revitalizácie do zmluvne dohodnutého termínu konca prenájmu. Ked’že objekt stále vlastní Bratislavský Samosprávny Kraj (BSK) a Nadácia Nová Cvernovka je v objekte zmluvne v prenájme na 25 rokov, koniec hodnotenej doby je teda po 25 rokoch od začiatku revitalizácie a teda od roku 2017 do roku 2041. Nájomné pre BSK je $120000 €$ ročne a ked'že budova je majetkom BSK, je dohodnuté, že hodnota nájomného sa bude vyplácat' z použitých investičných nákladov. Dohodnuté investičné náklady sú maximálne $2200000 €$. Po vyplatení celej dohodnutej investičnej hodnoty sa začne reálne vyplácat' nájomné $120000 €$ ročne. Niektoré benefity sú zatial' iba v stave rozpracovanosti, prípadne pripravované do budúcna, ale ked'že tabul'ka je v čase 25 rokov, ich socio-ekonomická hodnota je počítaná od predpokladaného roku začiatku. Ide hlavne o "Zlepšenie stavu infraštruktúry pre kultúru", ked’že od budúceho roku bude v areáli prístupné workoutové ihrisko a o "Rozšírenie cyklotrás", ktoré sú plánované v roku 2025. Ked’že sa analýza rozprestiera v nezanedbatel'nom časovom úseku je nutné použit' diskontovanie ako nástroj na zohl'adnenie časovej hodnoty. Diskontná sadzba je určená na $5 \%$ ako klasická sadzba pri verejnom projekte. Na základe týchto výsledkov sa kumuluje každoročný čistý finančný tok a je teda možné príst' k predpokladanej dobe návratnosti danej revitalizácie, čo je hlavný ciel' práce.

\section{VÝSLEDKY}

Tab. 1 Tabul'ka analýzy benefitov použitých v analýze CBA rozprestretej spolu s diskontovaním v čase realizácie a prevádzky.

\begin{tabular}{|c|c|c|c|c|c|c|c|c|c|c|c|c|c|c|c|c|c|c|}
\hline 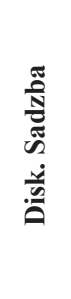 & 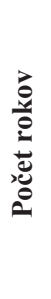 & $\stackrel{y}{\ddot{\theta}}$ & 竭 & $\underset{\sim}{\simeq}$ & $\hat{N}$ & $\underset{\mathbf{Z}}{\mathbf{Z}}$ & 盇 & 至 & 気 & 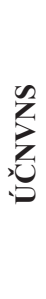 & $\frac{\underline{v}}{\sqrt[0]{n}}$ & $\begin{array}{l}\sum_{\infty}^{\infty} \\
\stackrel{2}{=} \\
\stackrel{5}{N}\end{array}$ & $\frac{N}{N}$ & $\sum_{\substack{n \\
N}}^{E}$ & 气 & $\underset{\simeq}{\cup}$ & 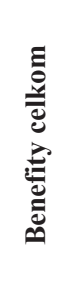 & 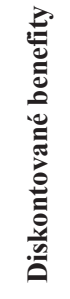 \\
\hline 1 & 1 & 2017 & 120 & 274 & 19 & 4 & 6 & 13 & 6 & 1 & 6 & & 5 & 3 & 3 & & 460 & 460 \\
\hline 0,95 & 2 & 2018 & 240 & 320 & 22 & 8 & 12 & 26 & 12 & 2 & 13 & & 9 & 6 & 6 & & 676 & 644 \\
\hline 0,91 & 3 & 2019 & 360 & 366 & 25 & 12 & 18 & 39 & 19 & 3 & 19 & & 14 & 9 & 10 & & 892 & 809 \\
\hline 0,86 & 4 & 2020 & 480 & 411 & 28 & 15 & 24 & 52 & 25 & 3 & 25 & & 19 & 12 & 13 & & 1108 & 957 \\
\hline 0,82 & 5 & 2021 & 600 & 457 & 32 & 19 & 30 & 65 & 31 & 4 & 32 & & 24 & 15 & 16 & & 1324 & 1090 \\
\hline 0,78 & 6 & 2022 & 600 & 457 & 32 & 19 & 30 & 65 & 31 & 4 & 32 & 9 & 24 & 15 & 16 & & 1334 & 1045 \\
\hline 0,75 & 7 & 2023 & 600 & 457 & 32 & 19 & 30 & 65 & 31 & 4 & 32 & 9 & 24 & 15 & 16 & & 1334 & 995 \\
\hline 0,71 & 8 & 2024 & 600 & 457 & 32 & 19 & 30 & 65 & 31 & 4 & 32 & 9 & 24 & 15 & 16 & & 1334 & 948 \\
\hline 0,68 & 9 & 2025 & 600 & 457 & 32 & 19 & 30 & 65 & 31 & 4 & 32 & 9 & 24 & 15 & 16 & 2 & 1336 & 904 \\
\hline 0,64 & 10 & 2026 & 600 & 457 & 32 & 19 & 30 & 65 & 31 & 4 & 32 & 9 & 24 & 15 & 16 & 2 & 1336 & 861 \\
\hline 0,61 & 11 & 2027 & 600 & 457 & 32 & 19 & 30 & 65 & 31 & 4 & 32 & 9 & 24 & 15 & 16 & 2 & 1336 & 820 \\
\hline 0,58 & 12 & 2028 & 600 & 457 & 32 & 19 & 30 & 65 & 31 & 4 & 32 & 9 & 24 & 15 & 16 & 2 & 1336 & 781 \\
\hline 0,56 & 13 & 2029 & 600 & 457 & 32 & 19 & 30 & 65 & 31 & 4 & 32 & 9 & 24 & 15 & 16 & 2 & 1336 & 744 \\
\hline 0,53 & 14 & 2030 & 600 & 457 & 32 & 19 & 30 & 65 & 31 & 4 & 32 & 9 & 24 & 15 & 16 & 2 & 1336 & 708 \\
\hline 0,51 & 15 & 2031 & 600 & 457 & 32 & 19 & 30 & 65 & 31 & 4 & 32 & 9 & 24 & 15 & 16 & 2 & 1336 & 675 \\
\hline 0,48 & 16 & 2032 & 600 & 457 & 32 & 19 & 30 & 65 & 31 & 4 & 32 & 9 & 24 & 15 & 16 & 2 & 1336 & 643 \\
\hline 0,46 & 17 & 2033 & 600 & 457 & 32 & 19 & 30 & 65 & 31 & 4 & 32 & 9 & 24 & 15 & 16 & 2 & 1336 & 612 \\
\hline 0,44 & 18 & 2034 & 600 & 457 & 32 & 19 & 30 & 65 & 31 & 4 & 32 & 9 & 24 & 15 & 16 & 2 & 1336 & 583 \\
\hline 0,42 & 19 & 2035 & 600 & 457 & 32 & 19 & 30 & 65 & 31 & 4 & 32 & 9 & 24 & 15 & 16 & 2 & 1336 & 555 \\
\hline 0,40 & 20 & 2036 & 600 & 457 & 32 & 19 & 30 & 65 & 31 & 4 & 32 & 9 & 24 & 15 & 16 & 2 & 1336 & 529 \\
\hline 0,38 & 21 & 2037 & 600 & 457 & 32 & 19 & 30 & 65 & 31 & 4 & 32 & 9 & 24 & 15 & 16 & 2 & 1336 & 503 \\
\hline 0,36 & 22 & 2038 & 600 & 457 & 32 & 19 & 30 & 65 & 31 & 4 & 32 & 9 & 24 & 15 & 16 & 2 & 1336 & 479 \\
\hline
\end{tabular}




\begin{tabular}{lllllllllllllllllll}
0,34 & 23 & 2039 & 600 & 457 & 32 & 19 & 30 & 65 & 31 & 4 & 32 & 9 & 24 & 15 & 16 & 2 & 1336 & 457 \\
0,33 & 24 & 2040 & 600 & 457 & 32 & 19 & 30 & 65 & 31 & 4 & 32 & 9 & 24 & 15 & 16 & 2 & 1336 & 435 \\
0,31 & 25 & 2041 & 600 & 457 & 32 & 19 & 30 & 65 & 31 & 4 & 32 & 9 & 24 & 15 & 16 & 2 & 1336 & 414 \\
\hline
\end{tabular}

Tab. 2 Tabul'ka analýzy nákladov použitých v analýze CBA rozprestretej spolu s diskontovaním v čase realizácie a prevádzky s kumulovaným čistým peňažným tokom (s použitím celkových benefitov z prechádzajúcej tabul'ky).

\begin{tabular}{|c|c|c|c|c|c|c|c|c|c|c|c|}
\hline 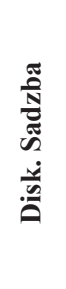 & 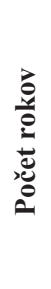 & 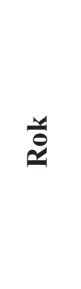 & Z & 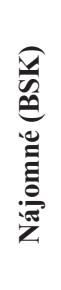 & 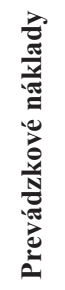 & 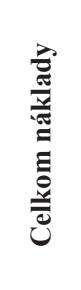 & 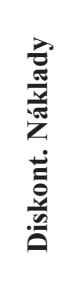 & 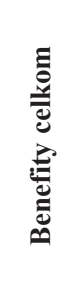 & 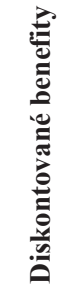 & 穵 & 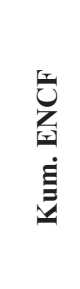 \\
\hline 1 & 1 & 2017 & 360 & 0 & 732 & 1092 & 1092 & 460 & 460 & -632 & -632 \\
\hline 0,95 & 2 & 2018 & 360 & 0 & 732 & 1092 & 1040 & 676 & 644 & -396 & -1028 \\
\hline 0,91 & 3 & 2019 & 360 & 0 & 732 & 1092 & 990 & 892 & 809 & -181 & -1209 \\
\hline 0,86 & 4 & 2020 & 360 & 0 & 732 & 1092 & 943 & 1108 & 957 & 14 & -1195 \\
\hline 0,82 & 5 & 2021 & 360 & 0 & 732 & 1092 & 898 & 1324 & 1090 & 191 & -1004 \\
\hline 0,78 & 6 & 2022 & 200 & 0 & 732 & 932 & 730 & 1334 & 1045 & 315 & -689 \\
\hline 0,75 & 7 & 2023 & 100 & 0 & 732 & 832 & 621 & 1334 & 995 & 374 & -314 \\
\hline 0,71 & 8 & 2024 & 100 & 0 & 732 & 832 & 591 & 1334 & 948 & 357 & 42 \\
\hline 0,68 & 9 & 2025 & & 0 & 732 & 732 & 495 & 1336 & 904 & 409 & 451 \\
\hline 0,64 & 10 & 2026 & & 0 & 732 & 732 & 472 & 1336 & 861 & 389 & 840 \\
\hline 0,61 & 11 & 2027 & & 0 & 732 & 732 & 449 & 1336 & 820 & 371 & 1211 \\
\hline 0,58 & 12 & 2028 & & 0 & 732 & 732 & 428 & 1336 & 781 & 353 & 1564 \\
\hline 0,56 & 13 & 2029 & & 0 & 732 & 732 & 408 & 1336 & 744 & 336 & 1900 \\
\hline 0,53 & 14 & 2030 & & 0 & 732 & 732 & 388 & 1336 & 708 & 320 & 2220 \\
\hline 0,51 & 15 & 2031 & & 0 & 732 & 732 & 370 & 1336 & 675 & 305 & 2525 \\
\hline 0,48 & 16 & 2032 & & 0 & 732 & 732 & 352 & 1336 & 643 & 290 & 2816 \\
\hline 0,46 & 17 & 2033 & & 0 & 732 & 732 & 335 & 1336 & 612 & 277 & 3092 \\
\hline 0,44 & 18 & 2034 & & 0 & 732 & 732 & 319 & 1336 & 583 & 263 & 3356 \\
\hline 0,42 & 19 & 2035 & & 80 & 732 & 732 & 304 & 1336 & 555 & 251 & 3607 \\
\hline 0,40 & 20 & 2036 & & 120 & 732 & 732 & 290 & 1336 & 529 & 239 & 3846 \\
\hline 0,38 & 21 & 2037 & & 120 & 732 & 732 & 276 & 1336 & 503 & 228 & 4073 \\
\hline 0,36 & 22 & 2038 & & 120 & 732 & 732 & 263 & 1336 & 479 & 217 & 4290 \\
\hline 0,34 & 23 & 2039 & & 120 & 732 & 732 & 250 & 1336 & 457 & 206 & 4496 \\
\hline 0,33 & 24 & 2040 & & 120 & 732 & 732 & 238 & 1336 & 435 & 197 & 4693 \\
\hline 0,31 & 25 & 2041 & & 120 & 732 & 732 & 227 & 1336 & 414 & 187 & 4880 \\
\hline
\end{tabular}

\section{DISKUZE}

Na základe tabul'ky je možné vidiet' že doba návratnosti je už niekedy v druhej polke ôsmeho roku od spustenia revitalizácie. Tento údaj sa dá označit' za viac než pozitívny a predurčuje podobné revitalizácie k vel'kej šanci na úspech. Je nutné podotknút’ že nie každá revitalizácia má k dispozícii tak dobré podmienky od vlastníka objektu, v tomto prípade Bratislavského Samosprávneho Kraju. 
Zároveň je ale nutné podotknút', že mnoho benefitov ešte nebolo v rámci tejto analýzy vyhodnotených kvôli chýbajúcim dátam, prípadne ešte nedostatočnému naplánovaniu. Jedná sa napríklad o plány vzniku materskej škôlky v spojení s takzvaným senior house-om. Toto spojenie sa v dnešnej dobe vo svete začína javit' ako vel'mi prospešné pre obe skupiny a na základe toho môže byt' vel'kým socio-ekonomickým benefitom v budúcnosti. Ďalej sa plánujú rôzne zlepšenia, čo sa týka vol'ných priestranstiev pre verejnost', kde budú uskutočňované benefičné koncerty a rôzne benefičné podujatia. Na základe týchto dát je možné určit', že táto špecifická revitalizácia môže slúžit' ako dobrý príklad pre d’alšie podobné projekty.

\section{ZÁVĚR}

Na základe ekonomického zhodnotenia prípadovej štúdie Nová Cvernovka je možné označit túto revitalizáciu za vel'mi úspešnú. Úspešnost' prípadovej štúdie predurčujú aj podmienky, ktoré majitel' objektu poskytol neziskovej nadácií, ktorá daný objekt revitalizovala. Revitalizovaním objektu vzniklo vel'ké množstvo socio-ekonomických benefitov so socio-ekonomickou hodnotou dostatočne vel'kou, aby spolu s priamymi príjmami prekonala náklady danej revitalizácie. Náklady danej revitalizácie boli pokryté grantovými príspevkami, za ktorých protiváhu môžeme pokladat' práve tieto benefity. V prípade, že by táto metodológia bola použitá na prípadné budúce revitalizácie, je možné vyvodit', či by malo využitie potencionálnych grantov zmysel na základe výsledkov ekonomického hodnotenia pomocou CBA analýzy, ktorá by porovnávala potencionálne náklady na revitalizáciu so socioekonomickými benefitmi a priamymi príjmami.

\section{Poděkování}

Tento článok bol uverejnený za podpory špecifického výskumu Vysokého učení technického v Brne Fakulty pod názvom FAST-J-21-7368 Postup hodnocení a druhy benefitů spojených s revitalizací brownfieldů.

\section{Použité zdroje}

[1] Kadeřábková B., Piecha M. Brownfields, how do they arise and what to do with them. 1st edition. Prague: C. H. BECK, 2009, ISBN 978-80-7400-123-9

[2] Atkinson G., Doick K.J., Burningham K., France C. Brownfield regeneration to greenspace: Delivery of project objectives for social and environmental gain. Urban Forestry \& Urban Greening. 2014, 13(3), 586-594

[3] Regenerace brownfields. PLANETA. 2007, XV(3), 21.

[4] Peřinková M. Current forms of use of industrial historical objects. Ostrava ; Prague: Gasset; Techné Ostrava, 2012. ISBN 978-80-87079-25-6.

[5] Korytárová J., Hromádka V. Veřejné Stavební Investice I. Studijní opora. Brno: VUT v Brně,.FAST, 2007.

[6] Brownfield Redevelopment in the European Union. Smart Brownfield Redevelopment for the 21st Century. 2007, (3), 19.

[7] Jackson B. Brownfields - the need for policy, startegy and an institutional framework. Transactions on Ecology and the environment: Brownfields III: Prevention, Assessment, Rehabilitation and Development of Brownfield Sites. , 26-29.

[8] Kreatívne a kultúrne centrum Nová Cvernovka. Dobré Mesto [online]. Bratislava: Ministerstvo dopravy a výstavby SR, 2020 [cit. 2021-11-12]. Dostupné z: https://dobremesto.gov.sk/obnovauzemi/skusenosti-miest/nova-cvernovka/

ECBA - evaluation of investment projects [online]. Brno, 2020 [cit. 2020-10-01]. Dostupné z: www.ecba.cz

[9] Klasifikácia a hodnotenie možností regenerácie brownfieldov. Uzemné plány [online]. [cit. 2021-12-20]. Dostupné z: https://www.uzemneplany.sk/zakon/klasifikacia-a-hodnotenie-moznosti-regeneraciebrownfieldov

[10] Finka M., 2010. Brownfield Redevelopment Planning - Territorial Conditions. In. Brownfield Handbook. Cross-disciplinary educational tool focused on the issue of brownfield regeneration. VŠB-TU Ostrava. s. 165. ISBN 978-80-248-2086-6.

[11] Sabo J., Hromádka V., Korytárová J. Efficiency of brownfields revitalization. 45th International Scientific Conference on Economic and Social Development. 2019. ISSN 1849-7535.

[12] Sabo J. a Hromádka V. Economic evaluation of small brownfield revitalization primarily for social use. 20th International Multidisciplinary Scientific GeoConference SGEM Vienna Green 2020. 2020. ISSN 1314-2704. 
[13] Sabo J. Ekonomické zhodnotenie revitalizácie brownfieldu za účelom predaju. Juniorstav 2020 - 22. odborná konference doktorského studia. ISSN 978-80-86433-73-8.

[14] Sabo J., Hromádka V. Economic evaluation of old barracks brownfield revitalization to support socially disadvantaged people. 63rd International Scientific Conference on Economic and Social Development Development - "Building Resilient Society", Book of Proceedings, 2020. ISSN 1849-7535. 